\title{
Body examinations of underage children committing crime - A Swedish perspective
}

\author{
KERSTIN NORDLÖF*
}

\section{Introduction}

In order to sentence a person who has committed a crime, he or she must at the time of the crime have reached the age of criminal responsibility, which in Sweden is 15 according to Chapter 1 Section 6 of the Swedish Criminal Code (SFS 1962:700). This age limit is also decisive regarding how a preliminary investigation shall be conducted when there is a suspicion of a crime, as well as for the use of coercive measures such as a body examination. The age of a crime suspect who is later prosecuted and convicted is also significant for determining the penalty. If the person is under the age of 18, special juvenile sanctions may be imposed and a prison sentence should be replaced with another kind of sanction, such as a locked facility for young people according to Chapter 30 Section 5 of the Criminal Code (SFS 2021:1103). The length of the sentence may not exceed 14 years and life imprisonment is excluded. Furthermore, the length of the sentence may be reduced with reference to the convict's age up to the age of 21 but not if she or he has reached the age of 18 and the sentence will be one year imprisonment according to Chapter 29 Section 7 of the Criminal Code (SFS 2021:1103).

The burden of proof regarding the age of the suspect rests with the police and the prosecutor respectively during the preliminary investigation and when using coercive measures. The court may also, based on its duty to investigate, request supplementary information from, for example, the Swedish Migration Agency, when there is uncertainty concerning the age of an accused.

The use of a coercive measure such as a body examination for the purpose of investigating whether a person, who is on reasonable grounds suspected of having committed a crime which carries a prison sentence, has reached the age of criminal responsibility has previously not been possible. When the suspect claimed to be under the age

* Kerstin Nordlöf, Professor of Law, School of law, psychology and social work at Örebro University. Email: Kerstin.Nordlof@oru.se

This is an Open-access article distributed under the terms of the Creative Commons Attribution 3.0 Unported License (http://creativecommons.org/licenses/ by/3.0/), permitting all use, distribution, and reproduction in any medium, provided the original work is properly cited. 
of 15 , a body examination could only be performed when it was of particular importance to clarify the circumstances of the crime according to Section 36a of the Young Offenders Special Provisions Act (SFS 1964:167). In 2017, however, the grounds for a body examination were extended to also include an investigation into the age of a suspect according to Chapter 28 Section 12 of the Swedish Code of Judicial Procedure (SFS 2017:435).

The question of the age of a suspect and particularly the burden of proof existed before the refugee crisis in 2015. An overview of the evidentiary requirements concerning the age of an accused indicates a variation in assessments made. This can be exemplified by referring to three court cases from 2005, 2013 and 2015. The case from 2005 determined that it was established 'beyond reasonable doubt' that the accused had reached the age of criminal responsibility. ${ }^{1}$ In the 2013 case, the evidentiary requirement was that the age of the accused should 'be clarified.' In the case from 2015, a lower standard of proof concerning 'predominant reasons' was applied. ${ }^{3}$

The extension of the requirements for the use of body examinations in 2017, derives from four very well-known cases. In the first case, Fåfängan from 2015, the prosecutor had presented as evidence of the age of the accused an ocular inspection consisting of the appearance, height, genital examination and voice of the accused. The Court of Appeal found that the ocular inspection had no value as evidence. It concluded on the basis of an overall assessment that information about the age of the accused provided by the accused, namely that he was 14 years old at the time, was not unjustified. Thus, it could not be established that the accused had turned 15 at the time of the crime. The Court therefore rejected the argument of the prosecution. ${ }^{4}$ In 2016, the Prosecutor-General applied to the Supreme Court to reopen the case based on new evidence indicating that the accused was in fact older than was earlier believed. The application was rejected since the possibility to open a case, which may potentially have a negative effect on a person, is very limited. No evidence concerning the crime was presented.

In the second case before the Court of Appeal from 2016, the question was whether the accused should be treated as an adult, meaning that he had reached the age of 21 when he was sentenced, or as an older adolescent. The Court of Appeal concluded that the information provided by the accused regarding the age should be accepted as proof if it did not appear 'unjustified' in the light of the prosecutor's evidence. ${ }^{5}$

1 The Court of Appeal, Göta hovrätt B 1325-05.

2 The Court of Appeal, Svea hovrätt B 905-13.

3 The Court of Appeal, for Västra Sverige B 1672-15.

4 The Court of Appeal, Svea hovrätt B 10485:15. For a discussion of the case see Wistrand, Åldersbedömning i brottmålsprocessen, Några reflektioner med anledning Svea hovrätts avgörande i "Fåfängan-målet", Svensk Juristtidning (2016) pp. 332-345.

5 The Court of Appeal, Svea hovrätt B 232-16. 
In the third case, in 2016, the Supreme Court concluded that it had to be clear that the accused had reached the age of criminal responsibility, the age of 15, when the crime was committed. This requirement regarding an assessment of the age of the suspect should be complied with when the prosecutor makes the decision to prosecute the suspect. Thus, the responsibility for assessing the age of the accused before a trial lies with the prosecutor. However, the court is as always responsible for ensuring that the required investigation is available at the trial. ${ }^{6}$

In the fourth and final case, also before the Supreme Court in 2016, the issue was whether a body examination, i.e. dental, wrist and collarbone x-rays and an MRI scan of the knee, to determine a person's age was permitted according to Chapter $28 \mathrm{Sec}-$ tions 11 and 12 of the Code of Judicial Procedure (SFS 1942:740). The Supreme Court rejected the application as the regulation in question only permits measures such as a body examinations, to investigate the crime. Thus, there were no legal grounds to conduct a body examination to define the suspect's age. ${ }^{7}$

The legal grounds with reference to the principles of proportionality, predictability, equal treatment and consistency for a body examination when the age of the suspect is unclear and he or she claims to be under the age of criminal responsibility are scrutinised in this article. The context of Article 3 of the Convention on the Rights of the Child (CRC) that states that 'the best interests of the child shall be a primary consideration' and similarly in Article 24:2 of the European Charter of Fundamental Rights, 'the child's best interests must be a primary consideration'. The article also elaborates on the impact the practice of a body examination in those specific situations may have from a gender and diversity perspective. Gender in this study refers to males and females while diversity is used here in the sense of an acceptance of and respect for people's differences.

\section{The Age of Criminal Responsibility}

\subsection{International Agreements}

Age as a parameter of criminal responsibility appears in several international agreements. Of particular interest in relation to the age of criminal responsibility in Sweden are the European Convention for the Protection of Human Rights and Fundamental Freedoms (ECHR), the $\mathrm{ECR}^{8}$ and the $\mathrm{CRC}^{9}$

$6 \quad$ NJA 2016 p. 719; For a discussion on determination on penalties at unclear age see Andersson, Påföljdsbestämning vid oklar ålder, 3 Juridisk Tidskrift (2016-17) pp. 712-721.

$7 \quad$ NJA 2016 p. 1165.

8 Charter of the Fundamental Rights of the European Union (2000/C 364/01).

$9 \quad$ Government Bill 2017/18:186. Inkorporering av FN:s konvention om barnets rättigheter. 
The age of criminal responsibility was considered by the European Court of Human Rights (ECtHR) in T. and V. v. the United Kingdom in 1999. The question was whether the trial of two ten-year-olds, who were accused of having murdered a small child, had violated Article 3 ECHR. The Article states that '[n]o one shall be subjected to torture or inhuman or degrading treatment or punishment'. The Court found that neither their age, the circumstances under which the trial took place, nor the fact that they were sentenced to imprisonment for an indeterminate period of time meant that they had been exposed to inhuman or degrading treatment. ${ }^{10}$ The ECR, like the ECHR, does not specifically deal with the age of criminal responsibility but may be brought up in cases before the ECtHR when the rights of the accused are at stake.

As opposed to the first two international agreements mentioned above, the CRC specifically deals with the issue of the age of criminal responsibility. Article 40(3)(a) establish that the states shall seek to promote in particular the establishment of a minimum age below which children shall be presumed not to have the capacity to infringe the penal law'. The CRC does not stipulate a certain age but that a minimum age should be established. The United Nations Committee on the Rights of the Child has asserted that the age should be 15 or 16 with reference to scientific findings, developmental and neuroscience evidence, which indicate that 'adolescent brains continue to mature even beyond the teenage years, affecting certain kinds of decision-making. ${ }^{11}$ The Child Rights International Network (CRIN) has argued that the General Comments of the Committee should encourage states to raise the minimum age closer to 18. ${ }^{12}$ This approach is supported by research which indicates that the human brain is typically not fully developed before the age of 25 , particularly when it comes to the assessment of risks. ${ }^{13}$

10 Still, the United Kingdom had not guaranteed the two sentenced boys a fair trial regarding consideration of the prerequisites for release although they had been deprived of their liberty for six years. This was found by the Court not to be in accordance with Article 5(4). The Court also found that the United Kingdom had not fulfilled the conditions in Article 6 that a court must decide the minimum time a sentenced person may be deprived of their liberty and not a government minister, which was the case when T. and V. were tried. Furthermore, the Court found that the two boys had not been able to take part in the trial in a suitable way which violated Article 6(1).

11 General Comment No. 24 (2019) on children's rights in the child justice systems, IV, C, 22.

12 CRIN.CommentsontheDraftrevisedGeneralCommentNo.10(2007)onchildren'srightsinthechild justice systems. 2019. www.ohchr.org/_layouts/15/WopiFrame.aspx?sourcedoc=/Documents/ HRBodies/CRC/GC10/CRIN.docx\&action=default\&DefaultItemOpen=1. 26 September 2019.

13 Knežević, Neurodynamic Correlates of Response Inhibition from Emerging to Mid-Adulthood, 36 Developmental Cognitive Neuroscience (2019) pp. 106-118. 


\subsection{Swedish Legislation}

In Sweden, the age of criminal responsibility is 15, in accordance with Chapter 1 Section 6 of the Criminal Code (SFS 1962:700). From time to time, arguments have been put forward in favour of lowering the age to $14 .{ }^{14}$ The age for criminal responsibility has varied but in the Penal Code from 1864, it was 15 and 14 in cases of 'severe criminality'. The exception providing that children at 14 years of age could be prosecuted when suspected of having committed a serious crime was removed in 1902. Children below the age of 15 were considered as not fully developed and thus could not be held responsible. ${ }^{15}$

During the drafting of the Criminal Code (SFS 1962:700), there were discussions regarding raising the age of criminal responsibility to 18 . Only a few adolescents below the age of 18 were in fact sentenced to sanctions for which the Prison and Probation Service was responsible. ${ }^{16}$ Such a proposal was never presented, and the age of criminal responsibility has remained at 15 since 1902. However, as opposed to the Penal Code of 1864, the Criminal Code (SFS 1962:700) provides that anyone can commit a crime such as for example theft, even someone under the age of 15 , but they cannot be held criminally responsible or in other words be prosecuted and sentenced. ${ }^{17}$

The idea of treating children differently from adults in criminal matters is partly based on the idea of protecting children including paying attention to fundamental principles of criminal law such as guilt, conformity and proportionality. A young person cannot be expected to have the same maturity and values as an adult. Crime may also be the result of a difficult situation at home and when the child was growing up. A young person is also more sensitive to punishment. Criminal acts committed by a young person therefore demand a greater understanding rather than condemnation. ${ }^{18}$ Recent research relating to the development of the brain, as referred to above, proves that raising the age for criminal responsibility would be more consistent with fundamental principles of criminal law. In other words, prosecuting and condemning someone demands that such a person has the ability to be held responsible for the criminal act.

14 See Lundgren, Sverige skulle kunna sänka straffbarhetsåldern till tolv år. Svt. 29 November 2018. https://www.svt.se/opinion/sverige-skulle-kunna-sanka-straffbarhetsaldern-till-14-13-ellerrent-av-12-ar. 26 September 2019.

15 The Penal Code of 1864 5:1-3 and 5:5; Agge and Thornstedt, Straffrättens allmänna del, 2nd ed. (Stiftelsen Juristförlaget 1978) p. 99.

16 Elwin, Den första stenen, 4th ed. (Tiden 1974) pp. 71, 319.

17 Jareborg, Handling och uppsåt (A. Norstedt och söner 1969) pp. 161, 342 f.

18 Sveri, Kriminalitet og alder (Almqvist \& Wiksell 1960). 


\section{Body Examinations of Crime Suspects}

\subsection{International Agreements}

A body examination is a coercive measure, consequently the principle of proportionality must be considered. This is necessary in order to protect the person in question and limit the state's authority to interfere, as stipulated in international agreements. The proportionality principle means that you may only resort to a body examination if the need for it outweighs the infringement the measure implies for the suspect or for any other conflicting interest and if less coercive measures cannot be used to achieve the same objective. Employing a coercive measure infringes a person's privacy, hence, the provisions must be interpreted restrictively. This particular coercive measure may only be used for a purpose stated in a law. Thus, this also emphasises that the use of this coercive measure must be based on a regulation. ${ }^{19}$ Since the focus here is children, another consideration has to be made - the best interests of the child must also be a primary consideration. This leads to a number of questions: is uncertainty of age a legitimate reason for a body examination when a suspect claims to be under the age of criminal responsibility? In such a situation, under what conditions may a body examination be performed and by whom? Additionally, what methods may be used and how reliable are their results?

Section I ECHR includes a positive obligation on states to protect individuals from infringements of their fundamental rights. Consequently, states are under a negative duty not to do certain things. ${ }^{20}$ Of relevance here is Article 3, lex specialis, which states that "no one shall be subjected to torture or to inhuman or degrading treatment or punishment'. The protection of individuals is stated in Article 4 of the ECR and in Article 37 (a) of the CRC, which relates to children specifically.

The United Nations Convention against torture and other cruel, inhuman or degrading treatment or punishment defines torture in Article 1 paragraph 1:

the term 'torture' means any act by which severe pain or suffering, whether physical or mental, is intentionally inflicted on a person for such purposes as obtaining from him or a third person information or a confession, punishing him for an act he or a third person has committed or is suspected of having committed, or intimidating or coercing him or a third person, or for any reason based on discrimination of any kind, when such pain or suffering is inflicted by or at the instigation of or with the consent or acquiescence 
of a public official or other person acting in an official capacity. ${ }^{21}$

Similarly, in Article 3 of the ECHR, torture is defined as an act which causes severe pain and suffering. The ECtHR has emphasised that the act has to include a minimum of severity. ${ }^{22}$ The applicability of this article as it relates to young persons in criminal proceedings was considered in the above-mentioned case of $T$. and $V v$. the United Kingdom. The Court found that neither the age of the suspects (they were 10), nor the public trial in an ordinary court which lasted for three weeks, implied that they had been exposed to inhuman and degrading treatment. The judgment issued by the Court may be interpreted as indicating that the Court was unwilling to include the impact a public trial in an ordinary court which lasted for three weeks might have on the mental health, within the definition of torture in Article 3 of the ECHR, on two 10-year-old children. The judgment thus constitutes a restrictive interpretation of Article 3. It might even be called into questioned whether the judgment of the Court contradicts the agenda of the CRC concerning the treatment of children suspected of having committed a crime and the definition of torture in Article 1 paragraph 1 of the United Nations Convention against torture and other cruel, inhuman or degrading treatment or punishment.

Article 8 of the ECHR covers the right to respect for a person's private life. A state cannot interfere with this protected right unless the three conditions provided in its second paragraph are fulfilled: 1) the interference is in accordance with the law, and 2) it is necessary in a democratic country in the interest of, among others, public safety, including, for example, protection against disorder and crime. According to the ECtHR, any interference in a person's private life must be due to a pressing social need. ${ }^{23}$ Furthermore, the interference in a person's private life must be proportionate to the purpose of the interference. ${ }^{24}$ The 2010 case of Gillan and Quinton v. the United Kingdom before the ECtHR dealt with a body search carried out in a public space without a reasonable suspicion of a crime. Furthermore, if the person refused to participate he/she risked facing criminal charges. The ECtHR concluded that the British counter-terrorism legislation from 2000 did not include sufficient legal safeguards and was thus a violation of Article 8 of the ECHR.

The ECtHR came to the same conclusion in Wainwright v. the United Kingdom in 2006. The case dealt with very intrusive body inspection of visitors to a prison to prevent drugs entering the prison. The right to respect for a person's private life is found in Article 3 of the ECR: 'Everyone has the right to respect for his or her physical and mental integrity'. On the right to respect for a person's private life, Article 16 of the

\footnotetext{
$21 \quad$ Adopted in 1984 and came into force in 1987.

$22 \quad$ Danelius 2015 p. $78 \mathrm{f}$.

23 See, for example, Herczegfalvy v. Austria, Storck v. Germany, Glass v. the United Kingdom, Y.E. v. Turkey.

$24 \quad$ Danelius 2015 p. 369 ff.
} 
CRC states that no child 'shall be subjected to arbitrary or unlawful interference with his or her privacy'. In relation to criminal procedures, Article 40 recognises that:

The right of every child alleged as, accused of, or recognised as having infringed the penal law to be treated in a manner consistent with the promotion of the child's sense of dignity and worth, which reinforces the child's respect for the human rights and fundamental freedoms of others and which takes into account the child's age and the desirability of promoting the child's reintegration and the child's assuming a constructive role in society.

Article 40 further states that States Parties shall, in particular, ensure that every child alleged as or accused of having infringed the penal law has a number of minimum guarantees, including 'to have his or her privacy fully respected at all stages of the proceedings'. According to the Committee of the Rights of Children, this mainly refers to preventing the child's identity from becoming public and that references to offences committed prior to the person reaching the age of 18 should not occur if the person later stands trial as an adult. ${ }^{25}$

The ECR also refers more specifically to the rights of the child and particularly to the principle of the best interests of the child. According to Article 24(2): '[I]n all actions relating to children, whether taken by public authorities or private institutions, the child's best interests must be a primary consideration'. Article 3 of the CRC also refers to the best interests of the child: 'in all actions concerning children, whether undertaken by public or private social welfare institutions, courts of law, administrative authorities or legislative bodies, the best interests of the child shall be a primary consideration. ${ }^{26}$ Prior to a decision to enforce legislation permitting a body examination of a child under the age of 15, the child's best interests shall 'be a primary consideration'. During the drafting of Chapter 28 Sections 12:3 of the Code of Judicial Procedure, allowing for a body examination to ascertain the age of a child suspected of having committed a crime, the child's perspective should have been, in accordance with CRC, considered, but it was not. This argument is based on the fact that young people are treated differently to older criminals when being sanctioned. ${ }^{27}$ Such considerations must also be, as clearly stated in Article 3 of the CRC, the most important issue when making the individual decision to perform a body examination on a child to ascertain its age.

25 General Comment No. 10 (2007) Children's rights in juvenile justice, CRC/C/GC/10, para 64.

26 For further information, see General Comment No. 14 (2013) on the right of the child to have his or her best interests taken as a primary consideration, Article 13(1), CRC/C/GC/14.

27 Government Bill 2016/17, Kroppsbesiktning i syfte att utreda ålder i brottmålsprocessen, p. 6 f. 


\subsection{Swedish Legislation}

The Swedish social services are responsible for the investigation when a child under the age of 15 is suspected of having committed a crime. The primary purpose of the investigation is to assess whether the child needs support or care from the social services. In the context of serious crimes, when the stipulated punishment is imprisonment of one year or more, there is an additional objective of uncovering how the crime was committed. In such situations, the police may initiate an investigation without prior consent from the social services - although the main issue remains to see whether the child needs support or care from the social services. ${ }^{28}$ Over the last two decades, the possibility of interfering in a child's private sphere has become very similar to the treatment of a person over 15 during a preliminary investigation. ${ }^{29}$ Instead of an investigation when the suspect is under the age of 15, a preliminary investigation may be initiated when the suspect has reached the age of 15 . If the age of the suspect is unclear, i.e. if it is unclear whether the suspect has reached the age of 15, there mainly needs to be a reason to assume that the suspect was 15 when the crime was committed to initiate a preliminary investigation. ${ }^{30}$

There are limited possibilities to use coercive measures when the suspect is under the age of criminal responsibility. A child may not, for example, be arrested or remanded in custody. Still, he or she may be apprehended if they are caught in the act or on the run from the scene of a crime that may lead to a prison sentence. ${ }^{31}$ Since 1985, a child suspect may be subjected to frisking but only if there are special reasons. ${ }^{32}$ As mentioned above, since 2010, the police authority may initiate an investigation when a very serious crime has been committed without the consent of the social services. ${ }^{33}$ Since 2010, photographs and fingerprints may also be taken of a suspect under the age of 15 , but only if the child is suspected of having committed a crime and special reasons prevail. Those measures may only be used in relation to an investigation of the alleged crime and not for identification in the future. ${ }^{34}$ The year 2010 also saw the introduction of the possibility of allowing a body examinations, but not with the purpose of clarifying the age of the child suspect. A body examination could only be resorted to when a child under the age of fifteen is suspected, on good grounds, of a particularly serious crime and only if a body search is particularly important to

$28 \quad$ SFS 1964:167 The Young Offenders Special Provisions Act, Section 31.

29 Nordlöf, Unga lagöverträdare i social-, straff- och processrätt, 2nd ed. (Studentlitteratur 2016) p. $264 \mathrm{ff}$.

30 Åklagarmyndigheten, RättsPM 2017:4, Åldersbedömning: Om handläggning av ärenden där den misstänkta personens ålder är oklar. Utvecklingscentrum Stockholm, June 2017, p. 3.

31 SFS 1964:167, Section 35.

32 SFS 1964:167, Section. 36.

33 SFS 1964:167, Section. 31.

34 SFS 1964:167, Section 36; Government Bill. 2005/06:165 Ingripanden mot unga lagöverträdare, p. $119 \mathrm{f}$. 
clarify the circumstances of the crime, which must be significant, and after careful consideration. Other alternatives which interfere less with personal integrity must always be considered in accordance with the principle of proportionality. If there are no available alternatives and there are reasons to believe that a body examination of a child will reveal the circumstances of the crime, a decision to perform a body examination may be lawful. When considering the principle of proportionality, special attention must be paid when a child is being exposed to a coercive measure. In general, the least restrictive measures should be used, in particular when resorting to a body examination, when it concerns children under the age of $15 .{ }^{35}$ When the regulation was introduced in 2017, ${ }^{36}$ it was stressed that children below the age of criminal responsibility are in a sensitive period of their development. This justifies taking special consideration of their personal integrity. The requirement for performing a body examination on a person who is not criminally responsible should therefore be stricter compared to the requirement applicable to a person who is 15 or older. ${ }^{37}$

Since 2017, a child suspect whose age is unclear and who claims to be under the age of 15 when the crime was committed may, given, that it may carry a prison sentence, be subjected to a body examination in order to find out whether they have reached the age of criminal responsibility or not. ${ }^{38} \mathrm{~A}$ decision concerning a body examination requires good grounds to assume that the suspect was 15 at the time of the crime. A body examination in such a situation should be performed restrictively. Prior to making a decision concerning a body examination, the person making the decision must assess how likely it is with regard to other circumstances, that the suspect is over 15. Thus, before a decision concerning a body examination may be made, the prosecutor or the person in charge of the preliminary investigation must collect information from, for example, previous interrogations or the Swedish Migration Agency. ${ }^{39}$ Hence, the lead investigator must continuously assess whether other measures may be taken to determine whether the suspect was over 15 when the crime was committed. A medical age assessment rarely suffices to clarify the age of the suspect. The existence of alternative means to assess age may mean that the suspect cannot be arrested. As an example, in a situation when an age assessment has been carried out and the results of that assessment are expected to take a long time, the suspect cannot be arrested as any deprivation of liberty will not be in accordance with the principle of proportionality. ${ }^{40}$

SFS 1964:167, Section 36a; SFS 1942:470 The Code of Judicial Procedure, Chapter 28 Section 12 paragraph 3; Government Bill 2009/10:105, Barn under 15 år som misstänks för brott, p. 50.

36 SFS 1942:470 The Code of Judicial Procedure, Chapter 28 Section 12 paragraph 3.

37 Government Bill 2009/10:105, p. 49 f.

38 SFS 1964:167, Section 36a; SFS 1942:470 The Code of Judicial Procedure, Chapter 28 Section 12 paragraph 3.

39 Åklagarmyndigheten, RättsPM 2017:4, 16; Åklagarmyndigheten, RättsPM 2013:6, Barn som begår brott - utredningar jämlikt 31\$ LUL, 17 ff.; Government Bill 2016/17:165, pp. 15 and 18.

40 Åklagarmyndigheten, RättsPM 2017:4, pp. 3 and 12. 
The extension of body examinations to include children claiming to be under 15 was motivated by the argument that otherwise serious crimes would not be investigated or prosecuted. The Government Bill stated that ' $\mathrm{t}]$ he demands of proportionality, predictability, equal treatment and consistency must also pertain to young people who commit crimes.'41 Still, nowadays there are, as described above, few differences between how a crime is investigated if the suspect is below or above the age of 15 . Furthermore, a child under the age of criminal responsibility who is considered to have committed a serious crime will most probably be taken into care, and even compulsory care, by the social services. Compulsory care means that the child is taken into care in a locked facility. Compulsory care may in those cases continue up to the age of 21 . The individual will also, regardless of any criminal prosecution, be liable for damages. Consequently, the difference between prosecuting a child or not doing so is not so evident for this particular group of children who claim to be under the age of criminal responsibility. The extension of the use of body examinations has instead made a difference to the State's obligation to respect a person's private life by increasing the possibilities of interfering in/violating a child's private sphere, and particularly their physical privacy. This is despite Sweden signing the CRC in 1990, which became law in 2020.

A prosecutor, the person in charge of the investigation or a court may issue a decision to perform a body examination on a child whose age is unclear and who claims to be under the age of 15 . A police officer may make such a decision if there is a risk in delaying further. ${ }^{42}$ In general, the prosecutor, the person in charge of the investigation or a police officer will make such a decision rather than a court. ${ }^{43}$ A court may make a decision for a body examination to be performed after a request by the prosecutor or lead investigator has been submitted. In cases of doubt, where there are, for example, difficult considerations to be made concerning proportionality, the prosecutor may thus submit a request to the court for a decision concerning a body examination. A decision concerning a body examination made by a prosecutor cannot be appealed against but it is subject to review. ${ }^{44}$ When it comes to providing evidence of the suspect's age, the requirement of the investigation must be set higher when assessing whether the accused is above the age of criminal responsibility, i.e. 15 years old. In these cases, the status of the investigation must be such that it is clear that the rules do not hinder the intended application of the law. ${ }^{45}$

Before a decision concerning a body examination is made, other avenues to determine the suspect's age must be investigated. Examples include contacting the embassy of the suspect's home country, Interpol which usually requires photographs and

\footnotetext{
41 SFS 1942:470 Chapter 28 Section 12 paragraph 1.3; Government Bill 2016/17:165, 5 f.

42 SFS 1942:470, Chapter 28 Section 13 paragraph 1.4.

43 Government Bill 2016/17:165, 6; Compare with NJA 2016, p. 1165.

44 Åklagarmyndigheten, RättsPM 2017:4 Åldersbestämning, p.16.

45 Government Bill 2016/17:165, 7 f.
} 
fingerprints of the suspect, information from interrogations with the suspect, and previous medical age assessments in the form of dental and skeletal $\mathrm{x}$-rays if the person has applied for asylum. The suspect's school, the healthcare system, the Swedish Migration Agency and the social services are under an obligation to provide information concerning the suspect, if requested, to the person in charge of the preliminary investigation. The legal requirement is that the crime may lead to a prison sentence, in some cases of over one year, or that the importance of the police being informed clearly takes precedence over the child's protected right to privacy. ${ }^{46}$

It is also recommended, prior to conducting a body examination which includes a medical age assessment, to discuss methods and assess whether there is any hindrance to carrying out such an age assessment, particularly if the suspect claims to be under $15 .{ }^{47}$ In accordance with the principles of necessity and proportionality, ${ }^{48}$ a decision concerning a body examination which includes a medical age assessment should not be made if the age of the suspect can be determined in a less intrusive way. ${ }^{49}$ If the penalty for the crime for an adult is a fine, it is never proportional to do a body search in order to carry out a medical age examination..$^{50}$

A person who is subjected to a body examination may be deprived of their liberty for six hours, or if special reasons prevail a further six hours to carry out the examination. ${ }^{51}$ That time limit must include both the carrying out of the body examination itself and the travel to and from the place of investigation. If the body examination takes longer, it cannot be performed unless the person has been either arrested or remanded in custody, and is therefore deprived of his/her liberty, or if the person has requested a medical age assessment him/herself. ${ }^{52}$

A body examination must, in general, be carried out by a doctor. ${ }^{53}$ The National Board of Forensic Medicine is responsible for carrying out body examinations, including age assessments to ascertain a suspect's age. The methods used are $\mathrm{x}$-ray examinations of wisdom teeth, hands and wrists. For x-ray examinations of wisdom teeth, two doctors must independently analyse the $\mathrm{x}$-ray to consider whether the wisdom teeth are considered fully developed or not. The same procedure is true for hands and wrists which must be examined by two independent radiologists. A medical age assessment

46 Åldersbestämning Probleminventering av frågor rörande åldersbestämning av unga lagöverträdare, Rapport oktober 2015 [ÅM-A 2014/1182]; Åklagarmyndigheten, RättsPM 2017:4, 14, 19-21; SFS 2009:400 Offentlighets- och sekretesslagen Chapter 10, Section 23, 24 and 27, Chapter 23 Section 2, Chapter 25 Section 1, Chapter 37 Section 1; NJA 2016, p. 1165.

47 Åklagarmyndigheten, RättsPM 2017:4, p. 15.

48 SFS 1942:470, Chapter 28 Section 13, first paragraph and Section 3a.

49 Åklagarmyndigheten, RättsPM 2017:4, p. 15 f.

50 Åklagarmyndigheten, RättsPM 2017:4, p. 18.

51 SFS 1942:470, Chapter 28 Section 13a paragraph 2.

52 Åklagarmyndigheten, RättsPM 2017:4, p. 15.

53 SFS 1942:470, Chapter 28 Section 13 paragraph. 2. 
usually consists of two examinations conducted at two different places and at different times. The National Board of Forensic Medicine relies on a probability scale when assessing age: shows that (no doubts about the age); speaks strongly in favour of (very high degree of certainty); speaks in favour of (high degree of certainty); possibly indicates (a lower degree of certainty); alternative ages possible but less likely; does not allow any assessment. ${ }^{54}$ When a person, a child in this context, risks future ill health or injury as a result of a body examination, such an examination may not be carried out. ${ }^{55}$ The results of the body examination and other material relating to the age of the suspect are presented to the court. ${ }^{56}$

The number of body examinations carried out in Sweden with the purpose of ascertaining a suspect's age was 6 in 2014, 15 in 2015, and 24 in $2016 .{ }^{57}$ Given that the regulation on body examinations to determine a suspect's age entered into force in 2017, those decisions were all made without any legal grounds. ${ }^{58}$

\section{Gender and Diversity in Criminal Matters}

\subsection{International Agreements}

The international agreements referred to in this article all make references to gender and diversity. Here, gender is applied in the context of male and female. Still, the term sex appears, particularly in international agreements. Diversity is studied in the context of nationality. According to Article 14 of the ECHR, rights and freedoms in the Convention should be secured without discrimination on any grounds such as, for example, sex and national origin. Thus, the protection against inhuman or degrading treatment, as well as the protection against interference in a person's private life, should be enforced without discrimination. It also means that all cases regarding the rights and freedoms of the Convention should be treated equally. Individuals whose situations are compared must be in an analogous situation. Differences between comparable situations must also have an objective and reasonable justification. A general prohibition against discrimination is included in Protocol 12 of the ECHR which has not been ratified by Sweden. ${ }^{59}$ Similarly, Article 21 of the ECR forbids discrimination due to sex and nationality. Article 2(1) of the CRC states that the 'States Parties shall respect and ensure the rights set forth in the present Convention to each child within

54 National Board of Forensic Medicine. Metoder för medicinska åldersbedömningar. https:// www.rmv.se/verksamheter/medicinska-aldersbedomningar/metoder/. 26 September 2019.

55 SFS 1942:470, Chapter 28 Section 12, last paragraph and last sentence.

56 Government Bill 2016/17:165, p. 8.

57 Government Bill 2016/17:165, p. 8.

$58 \quad$ NJA 2016 p. 1165.

$59 \quad$ Danelius 2015 pp. 549 ff. 
their jurisdiction without discrimination of any kind, irrespective of the child's ... sex, ... or, national origin ....

This article has discussed a number of relevant rights protected by international agreements, in relation to whether the suspect has reached the age of criminal responsibility: protection against inhuman and degrading treatment; respect for a person's private life; and, according to the ECR and CRC, the child's best interests. I will now elaborate on the question of whether there is discrimination or a risk of discrimination, for reasons of gender and diversity, in relation to those above-mentioned protected rights of persons. The context of children suspected of having committed a crime and whose age is unclear.

A child, whose age is called into question and who is therefore subjected to a body examination including an age assessment during the criminal procedure, is more likely to be male than female. This conclusion can be drawn both from data showing that crime among males is more prevalent than among females and from the cases presented in this article. ${ }^{60}$ Thus, the 2017 Regulation, allowing body examinations including an age assessment on child suspects claiming not to have reached the age of 15, cannot, with reference to the above-mentioned international agreements, be considered to discriminate or risk discriminating against males in relation to females, when it comes to being protected against inhuman and degrading treatment and respect for a person's private life.

Suspects subjected to a medical age assessment who have not received a personal identity number soon after birth in Sweden, can confirm their age in an official document such as a passport. ${ }^{61}$ Nor on this issue may discrimination occur in relation to being protected against inhuman and degrading treatment and respect for a person's private life. Consequently, when children who are suspected of having committed a crime, there are objective and sufficient reasons to distinguish between males who have no reliable information about their age, which means that they were not born in Sweden and most probably are not Swedish nationals, and males born in Sweden and females in general.

The child's best interests, as stated in both the ECR and CRC, shall be the goal without discrimination. Children, who may be subjected to a body examination are very vulnerable not only because of their age, but, in some cases, also because they are unaccompanied minors who came to Sweden to seek asylum. A regulation on body examination aimed at finding out the age of a child must be based on the principles of legality, proportionality, purpose and necessity but also that everyone should be treated equally. The measure must also be enforced restrictively. Still, the consequences

BRÅ, Misstänkta personer. www.bra.se/statistik/kriminalstatistik/misstankta-personer.html. 26 September 2019.

${ }_{61}$ See e.g., Article 7 of the CRC that states that a 'child shall be registered immediately after birth ...' 
of a body examination should be carefully considered when dealing with individuals claiming to be under the age of 15. This argument is also based on the fact that the overall assessment by the National Board of Forensic Medicine does not establish an exact age but rather concludes that it is more likely that the person is either above or under the age of 15 . To assess whether a child has reached the age of 15, further consideration of the choice of method is required according to the National Board of Forensic Medicine. ${ }^{62} \mathrm{~A}$ further argument to consider is the context. Those specific body examinations are enforced on males not born in Sweden and suspected of having committed a crime. Apart from the impact such a body examination will have on the person subjected to this particular coercive measure, it may also reinforce the view that foreign males are more criminal compared to males born in Sweden and females in general.

\subsection{Swedish Legislation}

Swedish legislation prohibits discrimination on the basis of sex or nationality. It is manifested in Chapter 1 Section 2 of the Instrument of Government (SFS 1974:152) which states that 'The public institutions shall combat discrimination of persons on grounds of gender ...national ...origin ..... Protection against discrimination is further specified in Chapter 2 Sections 12 and 13 stating that 'no act of law ... may imply the unfavourable treatment of anyone because they belong to a minority group by reason of ethnic origin, colour, or other similar circumstances, or on account of their sexual orientation', and similarly, an act of law may not 'imply the unfavourable treatment of anyone on grounds of gender .... When it comes to the rights of the child, Chapter 1 Section 2 states that 'public institutions shall promote the opportunity for... the rights of the child to be safeguarded'. In relation to the fundamental principles of criminal law, public authorities such as the police and prosecutors including the courts are obliged to treat everyone equally before the law, be objective and impartial, according to the Instrument of Government Chapter 1 Section 9.

When studying a legal issue on the basis of gender and diversity, we encounter both legal structures which focus on criminal procedures and social structures within the society. A structural approach explores how individuals are treated differently on a conscious and unconscious level, not because of their personal characteristics but because they either belong to or do not belong to a certain group. Differences in treat-

62 Compare with NJA 2016/17 712 and Andersson 2016-17 pp. 712-721. For further discussions see SOU 2021:84 Granskning av Rättsmedicinalverkets metod för medicinsk åldersbedömning i asylprocessen, p. $17 \mathrm{ff}$. 
ment may be assessed as unfair or not objectively motivated. Several legal scholars have described the construction of a structural approach. ${ }^{63}$

In this article, I focus on gender and diversity in the context of children whose age is uncertain in relation to the criminal procedure and society in general. Official data shows that more males are suspected on reasonable grounds of having committed a crime than females. ${ }^{64}$ The high rate of serious crime among males such as gross misdemeanour crimes, violent crimes and sexual crimes, is a major social problem. It is considered a result of the interaction between the subject, in this case the person suspected of having committed a crime, and social structures. To reduce crime among young males, research suggests that they must be 'liberated' from traditional male culture that allows and sometimes encourages crime and violence. We should work with young men's non-cognitive abilities, self-image and goal formulations. ${ }^{65}$ This is also in accordance with the gender equality work in Sweden where the focus is on masculinity norms and violence. ${ }^{66}$

A review shows that people who are not Swedish nationals or who have a parent born outside Sweden are treated differently within the judicial system. The results are based on information retrieved from the criminal register and the prosecution register. ${ }^{67}$ This group is also overrepresented when it comes to reported crimes and certain kinds of criminality. ${ }^{68}$ In special residential homes for young people, adolescents with a foreign background are also overrepresented. ${ }^{69}$

63 See, for example, Andersson, Hans (ord) eller hennes? En könsteoretisk analys av straffrättsligt skydd mot sexuella övergrepp (Bokbox förlag 2004); Lernerstedt, Dit och tillbaka igen: Om individen och strukturer i straffrätten (Iustus förslag 2010); Bladini, I objektivitetens sken (Makadam förlag 2013).

${ }_{64}$ BRÅ, Misstänkta personer. www.bra.se/statistik/kriminalstatistik/misstankta-personer.html 26 September 2019.

65 Bäckman et al, Könsskillnader i brottslighet - hur kan de förklaras?, 4 Ekonomisk Debatt (2018) p. 76.

66 En nationell strategi för att förebygga och bekämpa mäns våld mot kvinnor, in Makt, Mål och myndighet - feminstisk politik för en jämställd framtid Skr 12016/17:10.

$67 \quad$ Kardell, Diskriminering av personer med utländsk bakgrund i rättsväsendet - en kvantitativ analys, in SOU 2006:30 Är rättvisan rättvis: Tio perspektiv tio perspektiv på diskriminering av etnisk och religiös minoriteter inom rättssystemet, ed. Sarnecki (Fritzes) pp. 347-380.

68 Diesen, Negativ särbehandling i rättskedjans alla led, in SOU 2006:30 Är rättvisan rättvis: Tio perspektiv tio perspektiv på diskriminering av etnisk och religiös minoriteter inom rättssystemet, ed. Sarnecki (Fritzes) pp. 183-224.

69 Shannon, Ungdomar intagan på särskilda ungdomshem, in SOU 2006:30 Är rättvisan rättvis: Tio perspektiv på diskriminering av etnisk och religiös minoriteter inom rättssystemet, ed. Sarnecki (Fritzes) pp. 225-256. For further discussion see also Nordlöf 2016 pp. 369 and 386. 


\section{Discussion}

Knowing a person's age may be decisive in many situations, as for example when a person is suspected of having committed a crime. This article discusses the legal grounds for a body examination when the suspect's age is unclear and he or she claims to be under the age of criminal responsibility and what impact those decisions concerning body examinations may have from a gender and diversity perspective.

The age of criminal responsibility is discussed with reference to international agreements: the ECHR, the ECR and the CRC, which has had the status of Swedish law since 2020, as well as Chapter 1 Section 6 of the Swedish Criminal Code (SFS 1962:700). According to Article 1 CRC, a person is a child until he or she reaches the age of 18 . Article 40(3)(a) promotes the establishment of an age below which a child is presumed not to have the capacity to infringe penal law. The Committee on the Rights of the Child has argued that this age should be at least 14. The Child Rights International Network has argued that states should be encouraged to raise their minimum age closer to 18. According to Chapter 1 Section 6 of the Criminal Code (SFS 1962:700), the age of criminal responsibility is 15 . This does not imply that a child below this age cannot commit a crime, but that they cannot be held criminally responsible. This contradicts what is stated in Article 40(3)(a) CRC. The different perspective concerning a child's capacity to commit a crime below the age of criminal responsibility is interesting, particularly as the CRC was incorporated into law in Sweden in 2020.

The answer to the question of whether uncertainty of age is a legitimate reason for a body examination in the context of international agreements, such as the ECHR, the ECR and the CRC as well as the relevant Swedish legislation, is both yes and no. It refers to the rights to be protected from inhuman and degrading treatment and to have your privacy protected. However, with reference to the child's best interests, it is doubtful whether there are solid legal grounds with reference to the ECR and the CRC. According to Article 24(2) ECR: 'In all actions relating to children, whether taken by public authorities or private institutions, the child's best interests must be a primary consideration'. This is further developed by the CRC which in Article 3(1) more precisely states that: 'In all actions concerning children, whether undertaken by public or private social welfare institutions, courts of law, administrative authorities or legislative bodies, the best interests of the child shall be a primary consideration' In Sweden, this is more vaguely expressed in Chapter 1 Section 2 the Instrument of Government (SFS 1972:154) which states that children's rights must be safeguarded.

Since 2017, Chapter 28 Section 12 paragraph 1:3 of the Code of Judicial Procedure, (SFS 1942:740) enables the person in charge of an investigation, a prosecutor, a police officer in urgent situations and a court to make a decision concerning a body examination when a child claims to be under the age of criminal responsibility but there are good grounds to assume that the child had in fact reached the age of 15 when the crime was committed. The preparatory works indicate that there were attempts to include the child's best interests but this was never realised. The extension of the use of 
a body examination is based on the argument that serious crimes will otherwise not be investigated or prosecuted. Linked to the child's best interests in the preparatory works is the fact that the demands for proportionality, predictability, equal treatment and consistency must also apply to young people who commit crimes. The memorandum Åldersbedömning RättsPM 2017:4 produced by the Swedish Prosecution Authority includes detailed instructions on body examinations in these situations and emphasises that the principles of necessity and proportionality, and the requirement of evidence apply to body searches, for example, to determine whether a body examination may be performed. Still, the preparatory works and the memorandum do not indicate that there is an obligation to consider the child's best interests when making the decision to subject a child to a body examination. Thus, body examinations when the suspect's age is unclear and he or she claims to be under the age of 15 are not illegal. However, there is no requirement to ensure that the child's best interests are a primary consideration as stated in the ECR and the CRC.

The next question is whether uncertainty of age, when the suspect claims to be under the age of criminal responsibility, has a discriminatory effect, due to gender and diversity. This section focuses on the international agreements and Swedish legislation discussed above, but also on research which focuses on gender and diversity in criminal matters. According to Article 14 of the ECHR, Article 21 of the ECR, and Article 2(1) of the CRC, rights and freedoms must be secured without discrimination on any grounds, including sex and national origin. This article on body examinations has studied the protection against inhuman and degrading treatment and respect for a person's private life in depth. It has also illustrated that the child's best interests must be a primary consideration.

The issue is now whether there is discrimination or a risk of discrimination relating to these rights and freedoms when children claim to be under the age of criminal responsibility, are suspected of having committed a crime and their age is unclear. No discrimination or risk of discrimination may be found in relation to body examinations when the suspect's age is unclear. Nevertheless, a body examination may only be performed on children whose age is unclear. Most certainly, this means that a child with no personal identity number or without the required documents for identification, who is hence a foreign national or of foreign origin, is much more likely to be subjected to a body examination. The child is also most probably a male as males commit more serious crimes than females. Body examinations where the suspect claims to be under 15 years at the scene of the crime should be applied restrictively and not at all for more minor offences. We may also conclude that this group is very vulnerable as regards body examinations, not merely as a child but also potentially as an unaccompanied minor who arrived in Sweden to seek asylum.

The consequences of not taking primary consideration of the child's best interests when deciding whether to conduct a body examination on a child of unclear age who is suspected of having committed a crime and who claims to be under the age of crim- 
inal responsibility, must thus be understood in the light of social structures. These children are likely to be treated differently because they belong to a certain group. ${ }^{70}$ Even if there may be objective and reasonable reasons for distinguishing between, on the one hand, children suspected of a crime who have no reliable information of their age but claim to be under the age of 15, and, on the other, children born in Sweden who have a personal identity number, this may have an impact on criminal procedure and society at large. The medical age assessment that is mainly enforced on males and individuals who are not born in Sweden may reinforce structures according to which males are more likely to commit a crime than females. Similarly, it may also reinforce the notion that individuals born outside Sweden are more likely to commit a crime than individuals who do not have a foreign background. This has long-term negative repercussions on society from the perspective of gender and diversity. It also has direct negative effects on those directly involved: Notably a boy who is suspected of a crime which may lead to a prison sentence, who claims that he is under the age of 15 , but who is not believed by the lead investigator. In most cases, a young person who has committed a crime which may carry a prison sentence is likely to be in need of care, often compulsory care provided by the social services. Regardless of whether the boy, who claims to be under the age of 15 , is prosecuted or not, he will most probably end up in care. He will always be civilly responsible for damages.

The use of body examinations on children who claim to be under the age of criminal responsibility may affect how different groups in a multicultural society perceive each other, but also how individuals within a given group perceive themselves. Thus, coercive measures used on children may have a negative impact from a gender and diversity perspective, in the sense that they may preserve prevailing structures where men and women with a foreign background commit more severe crimes than men and women born in Sweden. The best interests of the child, together with gender and diversity perspectives, should have been duly considered when the impactful decision concerning body examinations on children claiming to be under the age of 15 when a crime was committed was introduced. This would have been in compliance with Article 3 of the CRC which states that 'the best interests of the child shall be...' and similarly in Article 24:2 of the European Charter of Fundamental Rights, 'the best interests of the child shall be a primary consideration'. An awareness of structures, which may have a negative impact on society at large in the long-term, is necessary to implement a sustainable criminal procedure when enforcing the Swedish Criminal Code (SFS 1962:700). 